Universitas Ubudiyah Indonesia

e-ISSN : 2615-5346

\title{
Game Sejarah Presiden Republik Indonesia Berbasis Android dengan Menggunakan Teknik Steganography
}

\section{President of the Republic of Indonesia History Game Based on Android Using Steganography}

\author{
Techniques \\ Fathiah, ${ }^{l}$ Ely Rahmi ${ }^{2}$
}

Prodi Teknik Informatika Fakultas Ilmu Komputer, Universitas Ubudiyah Indonesia

Prodi Teknik Informatika Fakultas Ilmu Komputer, Universitas Ubudiyah
Jl. Alue Naga Tibang. Kec. Syiah Kuala, Banda Aceh, Indonesial dan 2
Email: fathiah@uui.ac.id ${ }^{l}$ rahmiely1 @ gmail.com ${ }^{2}$

\begin{abstract}
Abstrak- Permainan atau game merupakan salah satu perkembangan teknologi informasi yang sangat pesat saat ini, game merupakan permainan yang dapat menghibur diwaktu luang dan sekaligus dapat dijadikan sebagai media pembelajaran. Game yang akan dibangun pada aplikasi android ini berhubungan dengan Sejarah Presiden Republik Indonesia menggunakan Steganography. Presiden adalah kepala negara, presiden dibantu oleh wakil presiden serta para mentri yang duduk dalam kabinet pemerintahan. Game Sejarah Presiden Republik Indonesia ini dirancang berdasarkan hasil pengamatan dan wawancara mengenai sistem pembelajaran dan minimnya ilmu pengetahuan siswa tentang sejarah presiden republik indonesia, khususnya pelajaran sejarah pada SD Negeri Limpok Aceh Besar. Tujuan pembuatan game Sejarah Presiden Republik Indonesia berbasis android diharapkan dapat mempermudah guru dalam proses mengajar, sebelumnya proses pembelajaran sumber informasinya adalah guru dan bahan bacaan dan membangkitkan semangat belajar siswa tentang sejarah presiden republik indonesia. Pada aplikasi game yang dibangun menggunakan steganography, steganography adalah pesan tersembunyi atau menyembunyikan pesan, baik dalam bentuk gambar maupun dalam bentuk teks.
\end{abstract}

Kata Kunci : Game, Steganography, Presiden RI

\begin{abstract}
Game is one of the rapid development of information technology today, the game is a game that can entertain in spare time and at the same time can be used as a medium of learning. The game will be built on this android app related to the history of the President of the Republic of Indonesia using Steganography. The President $i$ the head of state, the president is assisted by the vice president and ministers who sit in government cabinet. Game History of the President of the Republic of Indonesia is designed based on the results of observations and interviews about the learning system and the lack of knowledge of students about the history of the president of the republic of Indonesia, especially history lessons at Limpok Aceh Besar Primary School. The purpose of game making History of the Republic of Indonesia based on android expected to facilitate teachers in the teaching process, previous learning process of the source of information is the teacher and reading material and inspire the spirit of student learning about the history of the president of the republic of Indonesia. In game applications built using steganography, steganography is a hidden message or hide messages, either in the form of images or in text form.
\end{abstract}

\section{Keywords: Game, Steganography, President of RI}

\section{PENDAHULUAN}

Perkembangan teknologi informasi yang sangat pesat saat ini, sedikit banyaknya telah mempengaruhi seluruh kalangan masyarakat, khususnya dibidang permainan yang didukung oleh perkembangan software. Permainan saat ini sudah mulai beralih ke arah mobilesmartphone, yang memungkinkan pemain untuk memainkan permainan dimana saja dan kapan saja. Salah satu sistem operasi mobilesmartphone yang sedang berkembang saat ini adalah sistem operasi Android. Sistem operasi Android bersifat terbuka sehingga memberi kesempatan bagi para pengembang untuk menciptakan aplikasi mereka sendiri, terutama aplikasi permainan. Aplikasi permainan berkembang pesat di sistem operasi Android. Salah satu permainan yang dapat dikembangkan di sistem operasi Android adalah Game Sejarah Presiden Republik Indonesia.

Indonesia pasti memiliki sejarah, bahkan tiap negara juga memiliki sejarah tidak terkecuali. Indonesia memiliki banyak sejarah salah satunya adalah sejarah mengenai presiden. Presiden adalah kepala Negara Indonesia, presiden dibantu oleh wakil presiden dan para mentri-mentri yang duduk di bangku kabinet. Berdasarkan penelitian yang dilakukan pada SDN Limpok Aceh Besar, sangat disayangkan ada siswa/i yang tidak mengetahui siapa-siapa presiden yang pernah menjabat selama Negara Republik Indonesia terbentuk. Ada siswa/i yang mengetahui, tetapi mereka masih salah menyebut atau nama-nama Presiden yang disebut sering sekali tertukar-tukar dalam periode jabatannya. Di SDN Limpok juga minimnya media pembelajaran khususnya mata pelajaran sejarah berkaitan dengan Sejarah Presiden Republik Indonesia. Media saat ini yang digunakan hanya dalam bentuk buku ajar sejarah yang tersedia di sekolah.

Berdasarkan permasalahan diatas, maka penulis ingin membuat sebuah Game Sejarah Presiden Republik Indonesia berbasis Android dengan menggunakan Teknik Steganography yang dapat membantu siswa atau guru dalam sistem pembelajaran tentang Sejarah Presiden Republik Indonesia. Dengan adanya game ini diharapkan dapat membantu siswa dalam penambahan wawasan tentang Sejarah Presiden Republik Indonesia. Selain menambah wawasan 
Journal of Informatics and Computer Science Vol. 4 No. 2 Oktober 2018

Universitas Ubudiyah Indonesia

e-ISSN : 2615-5346

game ini juga dapat digunakan sebagai sarana hiburan di waktu luang.

\section{STUDI PUSTAKA}

\subsection{Profi SD Negeri Limpok}

Sekolah adalah sebuah lembaga pendidikan yang formal yang didiri oleh Negara dan dirancang untuk mengajari siswa dengan bimbingan dari guru (www.pengayaan.com, diakses 20 Desember 2017, 20:30). Sekolah Dasar Negeri (SDN) Limpok terletak di jalan Tgk. Syik Dipasi Desa Limpok, RT/RW 0/0, Desa Limpok Kecamatan Darussalam Kabupaten Aceh Besar Provinsi Aceh. SDN Limpok Izin Operasional pada tanggal 11 Agustus 2004, dengan Kode Pos 23373.

\subsection{Presiden}

Presiden ialah kepala negara (dibantu oleh seorang wakil presiden) yang juga menjabat sebagai kepala Ekseklusif. Dewan pertimbangan Agung DPA (bertugas sebagai badan penasehat presiden). Majelis Permusyawaratan Rakyat (MPR). Sebagai badan pemerintahan tertinggi dan memegang kedaulatan rakyat menentukan haluan Negara. Presiden melaksanakan keputusan-keputusan MPR dan juga bertanggungjawab kepadanya. Tugas perundangundangan (legislatif).

\subsection{Game}

Game berasal dari kata bahasa inggris yang memiliki arti yang dasar "Permainan". Permainan dalam ini merujuk kepada pengertian "kelincahan intelektual". Game juga bisa di artikan sebagai arena keputusan dan aksi permainannya. Ada target-target dan misi untuk dapat dicapai pemainnya. Kelincahan intelektual, pada tingkat tertentu merupakan ukuran sejauh mana game itu menarik untuk dimainkan secara maksimal.

Game adalah media pembelajaran masa kini. Manusia mempunyai sifat dasar lebih cepat mempelajari segala sesuatu secara visual-verbal, sehingga game juga baik jika dilibatkan dalam proses pendidikan (game edukasi).

\subsection{Pengenalan Android}

Android merupakan sebuah sistem operasi perangkat monile berbasis Linux, yang mencakup sistem operasi, midleware dan aplikasi. Generasi baru platform mobile, platform yang memberikan pengembangan untuk melakukan pengembangan sesuai dengan yang diharapkan. Sistem operasi yang mendasari android dilesensikan dibawah GNU, General Public License Versi 2 (GPL 2), yang lebih dikenal dengan istilah copyleft, lisensi dimana setiap perbaikan pihak ketiga harus terus dibawah syarat (terms), Android didistribusikan dibawah License Apache Software yang memungkinkan untuk dstribusi kedua dan

seterusnya.

Komersialisasi pengembangan dapat memilih untuk meningkatkan platform tanpa harus memberikan perbaikan mereka ke masyarakat open source. (Yuniar, $2015: 1$ ).

\subsection{Steganography \\ Steganography adalah seni dan ilmu menulis pesan tersembunyi atau menyembunyikan pesan dengan suatu cara sehingga selain si pengirim dan si penerima, tidak ada seorangpun yang mengetahui atau menyadari bahwa ada suatu pesan rahasia.}

\section{METODE}

\subsection{Jenis Penelitian}

Penelitian ini menggunakan metode penelitian deskriptif karena dalam pelaksanaannya meliputi data, analisis dan interpretasi tentang arti dan data yang diperoleh. Penelitian ini disusun sebagai penelitian induktif yakni mencari dan mengumpulkan data yang ada di lapangan dengan tujuan untuk mengetahui faktor-faktor, unsur-unsur bentuk, dan suatu sifat dari fenomena.

\subsection{Alat dan Bahan}

Dalam perancangan game sejarah presiden republik indonesia diperlukan perangkat keras yaitu 1 unit laptop dan 1 unit smartphone dan perangkat lunak yaitu android Studio, Jdk 8, Coreldraw.

\section{Hasil Penelitian dan Pembahasan \\ 4. 1 Implementasi Sistem}

Pada Game Sejarah Presiden Republik

Indonesia berbasis Android dengan menggunakan teknik Stegnography ini, dapat dijalankan pada smartphone dan memiliki 7 level bermain dan menggunakan teknik penyembuyian gambar, yaitu gambar Presiden Republik Indonesia. Game yang telah dibagun akan di implementasikan untuk mengetahui apakah game tersebut dapat berjalan sesuai dengan tujuannya atau tidak.

\subsubsection{Implementsi Kebutuhan Perangkat}

Adapun perangkat keras dan perangkat lunak yang digunakan untuk melakukan implementasi dan pengujian game ini, sebagai berikut :
a. Perangkat Keras
Dalam perancangan game sejarah presiden republik indonesia ini memerlukan 1 (satu) unit laptop asus dan 1 (satu) unit smartphone Oppo.

b. Perangkat Lunak 
Journal of Informatics and Computer Science Vol. 4 No. 2 Oktober 2018

Universitas Ubudiyah Indonesia

e-ISSN : 2615-5346

Dalam pembuatan game ini memerlukan perangkat lunak yaitu Android Studio, JDK 8 dan Corel Draw X6.

\subsubsection{Implementasi Antar Muka (interface)}

Game Sejarah Presiden Republik Indonesia adalah game yang memiliki fungsi sebagai media pembelajaran mengenai Sejarah dan sosok Presiden. Republik Indonesia dan manpu menyembunyikan (steganography) sosok gambar presiden. Untuk mempermudah dalam penggunaan game ini, berikut terdapat tahap-tahap dalam penggunaannya.

\subsubsection{Tampilan Halaman Awal Game Pada} tampilan ini, muncul ketika user menjalankan game sejarah presiden republik indonesia. Tampilan halaman awal game dapat dilihat pada Gambar 4.1.

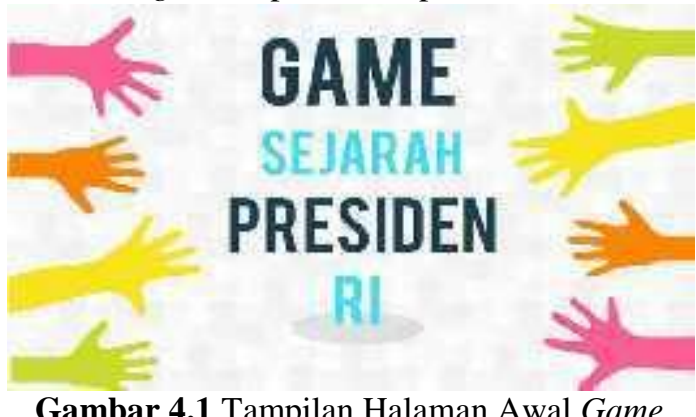

\subsubsection{Tampilan Halaman Utama}

Pada Tampilan Halaman Utama game Sejarah Republik Indonesia ini memiliki 3 tampilan menu yaitu menu permainan baru, bantuan dan keluar. 3 menu tersebut memiliki fungsi masing-masing yaitu:

1. Menu permainan baru berfungsi untuk memulai permainan.

2. Menu bantuan berfungsi untuk menolong user untuk memberi petunjuk atau cara bermain pada game ini.

3. Menu keluar berfungsi untuk keluar dari permainan game.

Tampilan halaman dapat dilihat pada Gambar 4.2.

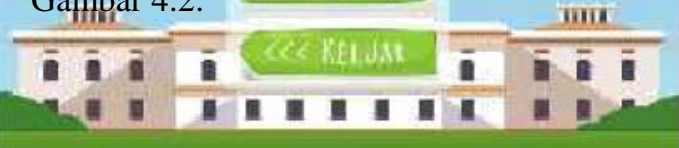

Gambar 4.2 Tampilan Menu Awal

\subsubsection{Tampilan Halaman Bantuan}

Tampilan halaman bantuan ini memiliki tampilan yang berisi teks, yaitu tulisan berupa

petunjuk cara bermain pada game sejarah presiden republik indonesia. Pada tampilan ini juga memiliki menu back atau kembali, berfungsi untuk kembali kehalaman awal. Tampilan halaman dapat dilihat pada Gambar 4.3 .

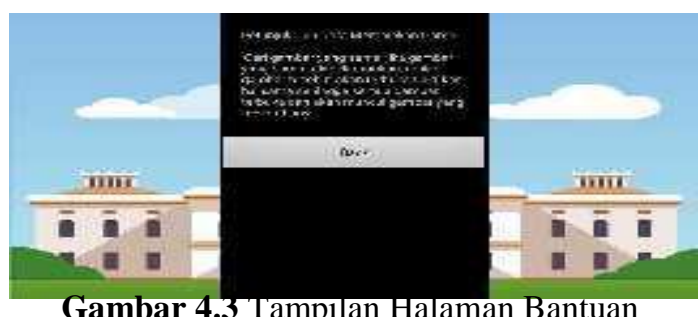

\subsubsection{Tampilan Halaman Bermain}

Pada tampilan halaman bermain ini memiliki tombol-tombol untuk bermain game . Pada game ini memiliki 7 level bermain, semakin tinggi level bermain maka semakin sinkat waktu yang diberikan untuk si pemain atau user. Game ini juga memiliki Score bermain. Tampilan halaman dapat dilihat pada Gambar 4.4

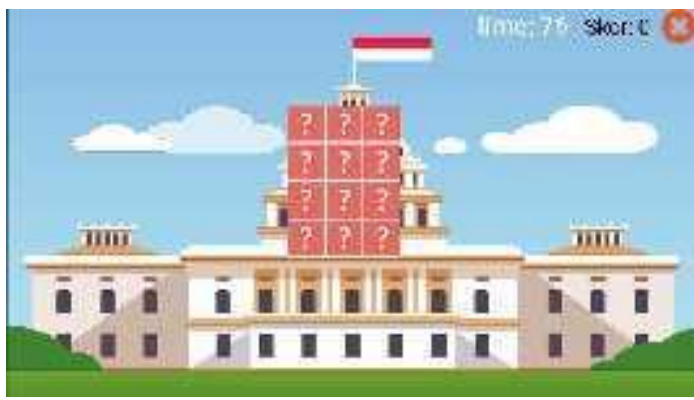

Gambar 4.4 Tampilan Halaman Bermain

Pada halaman bermain ini, user harus mencari gambar pasangannya, jika tombol yang di tekan tidak menemukan pasangan gambar yang sama maka secara otomatis gambar akan tertutup kembali. Tampilannya dapat dilihat pada Gambar 4.5, tetapi jika si user dapat menemukan gambar pasangannya maka gambar yang dicocokkan akan berhenti terbuka dan menghilang. Tampilan halaman dapat dilihat pada Gambar 4.6

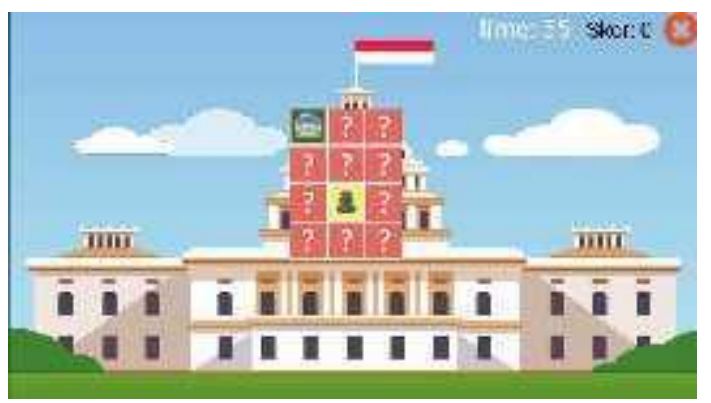

Gambar 4.5 Tampilan tidak mendapatkan Pasangan Gambar
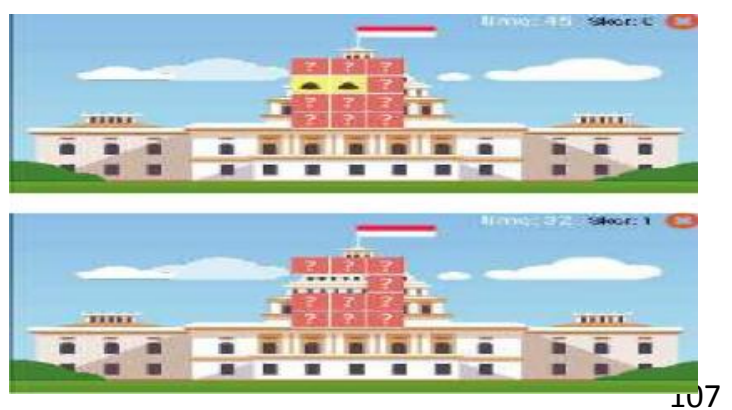
Journal of Informatics and Computer Science Vol. 4 No. 2 Oktober 2018

Universitas Ubudiyah Indonesia

e-ISSN : 2615-5346

Gambar 4.6 Tampilan Setelah menemukan Pasangan Gambar

\subsubsection{Tampilan Game Over}

Pada game sejarah presiden republik indonesia ini memiliki waktu untuk bermaian, jika si user habis waktu saat bermain maka game secara otomatis mati atau yang sering kita dengar yaitu game over. Tampilan halaman dapat dilihat pada Gambar 4.7.

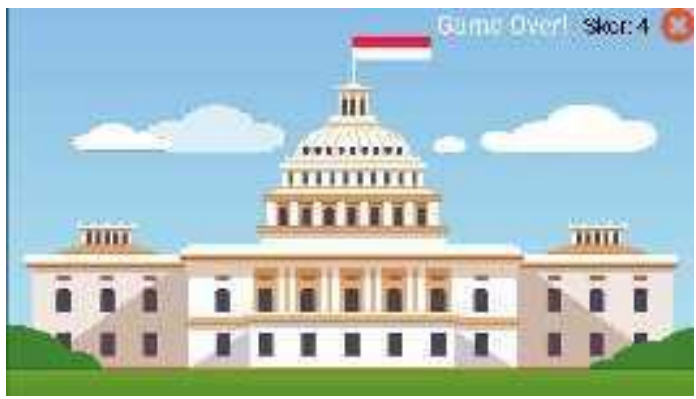

Gambar 4.7 Tampilan Game Over

Jika tombol-tombol yang ada pada tampilan halaman bermain berhasil menemukan gambar pasangannya masing-masing maka tombol dan gambar tersebut akan hilang dan akan muncul gambar Presiden Republik Indonesia yang tersembunyi, yaitu teknik Steganography. Pada tampilan ini terdapat 3 menu yang memiliki fungsi sebagai berikut:

1. Menu lanjut berfungsi untuk melanjutkan ke level selanjutnya

2. Menu keluar berfungsi untuk kembali kehalaman utama tersebut.

3. Menu play berfungsi untuk mendengarkan cerita atau sejarah tentang presiden dalam bentuk audio atau suara.

Tampilan halaman dapat dilihat pada Gambar 4.8 .

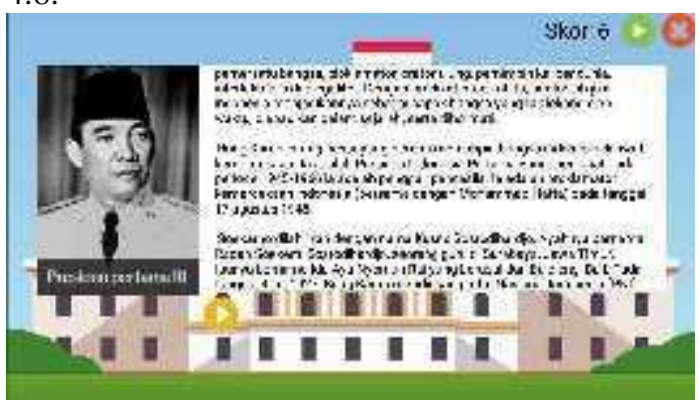

Gambar 4.8 Tampilan Gambar yang di Sembunyikan (Steganography)

\section{KESIMPULAN}

Berdasarkan hasil pembahasan dan pengujian sistem Rancang Bangun Game Sejarah Presiden Republik Indonesia Berbasis Android dengan menggunakan teknik Steganography dapat disimpulkan bahwa:

1. Game Sejarah Presiden Republik Indonesia ini, dapat dijalankan diberbagai Smartphone, dengan bukti berdasarkan pengujian aplikasi game ini pada Oppo Neo7 dan Xiomi Redmi 4A.

2. Berdasarkan hasil penelitian Game Sejarah Presiden Republik Indonesia pada murid SD Negeri

Limpok, bahwa game ini dapat dijadikan media pembelajaran tentang sejarah Presiden Republik Indonesia.

\section{DAFTAR PUSTAKA}

Asimah Asizun, Namin. 2015. Ensiklopedia Kabinet Kerja UUD 1945. Jakarta: Kunci Aksara

Basyaib, Fachmi. 2015. Teori Pembuatan Keputusan. Yogyakarta: Grasindo.

Hojanto, Ongky. 2013. Public Peaking Mastery. Jakarta: PT. Garamedia Pustaka Utama.

Meier, R. 2012. Professional Android Aplication Development. Wiley Publishing, Canada

Setiawan, Yohan Adi. 2017. Belajar Android Menyenangkan. Surabaya:CV. Cipta Media Edukasi.

Suito, Deny dan Muarif, Samsul. 2009. President Idol Pertarungan Sengit 10 Capres Menuju RI-I. Jakarta Selatan: Grafindo Khazana Ilmu.

Supardi, Yuniar. 2015. Belajar Coding Android Bagi Pemula. Jakarta: PT. Alex Media Komputindo.

Sudarwanto, Hendry. 2013. Sisi Lain Para Bapak Bangsa.Yogyakarta:Palapa. Utami, Ema. 2009. Pendekatan Metode Least Bit odification untuk Merancang Aplikasi Steganography pada File Audio Digital Tidak Terkompresi. Jurnal DASI 10.

Sulistyowati. 2015. Buku Cerdas UUD \& Amanden Perubahannya. Yogyakarta.

Nelly. 2012. Membangun Game Edukasi Sejarah Walisongo Menggunakan Algoritma Best first Search. Bandung: FTIK UNIKOM.

www.seklogo.com, diakses pada tanggal 30 November 2017.

www.theinspirationroom.com, diakses pada tanggal 30 November 2017. www.technocollit.com , diakses pada tanggal 30 November 2017

www.referensi.data.kemdikbud.go.id, diakses 24 Januari 2018. www.wikiwand.com, diakses 20 Januari 2018

www.beritauberita.com, diakses 20 Januari 2018 